\title{
Az Európai Horizont kutatási és innovációs keretprogram (2021-2027)
}

\section{Horizon Europe - the next research and innovation framework programme (2021-2027)}

Szitáné dr. Kazai Ágnes, tanácsadó

Semmelweis Egyetem, Innovációs Központ

kazai.agnes@semmelweis-univ.hu

Initially submitted March 16, 2020; accepted for publication Apr.28, 2020

\begin{abstract}
Key features in Horizon Europe:

- Three pillars

- European Innovation Council

- R\&I missions

- Strengthening international cooperation

- New approach to European partnerships

- Open science policy across the programme

- Widening participation and spreading excellence

- Reducing administrative burdens
\end{abstract}

The European Commission published its proposal for a new research and innovation framework programme in June 2018. Horizon Europe and the Euratom Research and Training Programme (with a $€ 100$ billion proposed budget for 2021-2027) will become the most ambitious research and innovation funding programme ever. The main aims of Horizon Europe are to strengthen science and technology, to foster industrial competiveness, and to implement the sustainable development goals in the EU.

Kulcsszavak: kutatás és innováció, Európai Horizont keretprogram, pillérek, küldetések, európai partnerségek

Keywords: research \& innovation, Horizon Europe framework programme, pillars, missions, European partnerships

A Kaleidoscope 2012. évi 4. számában jelent meg az európai kohéziós és innovációs politika jövőjéről szóló ismertetés, amely a 2014. és 2020. közötti időszakra vonatkozó uniós költségvetés (többéves pénzügyi keretek, Multiannual Financial Framework, MFF) és támogatások fontosabb elemeit foglalta össze. ${ }^{1}$ Az összegzés kiemelten foglalkozott a Horizont 2020 (H2020) elnevezésü, az Európai Unió kutatás, innováció és a versenyképesség előmozdítását célzó - keretprogramjának bemutatásával. Az idő gyorsan múlik; e keretprogram a végéhez közeledik, és 2021 januárjától átadja helyét „utódjának”.

\section{Az Európai Bizottság javaslata az új keretprogramra}

Az Európai Bizottság 2018 júniusában tett javaslatot az új keretprogram létrehozására és szabályozására. ${ }^{2}$ Az ún. Európai Horizont programra vonatkozó javaslatcsomag részei a következők: 
1. az Európai Horizont kutatási és innovációs keretprogram, amely magában foglalja a részvételi és terjesztési szabályokat is;

2. az Európai Horizont végrehajtását szolgáló egyedi program;

3. az Európai Horizontot kiegészítő, az Euratom-szerződés szerinti kutatási és képzési program;

4. a kapcsolódó hatásvizsgálat és pénzügyi kimutatások.

Az Európai Horizont program általános és egyedi céljai a következők:

\section{Általános célok}

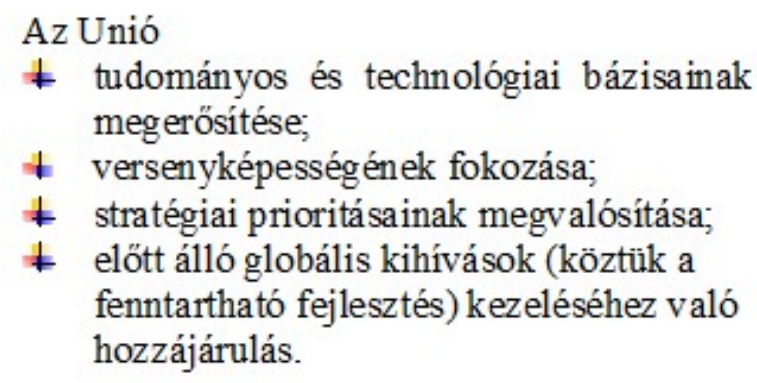

\section{Egyedi célok}

* a magas színvonalú, új ismeretek, készségek, technológiák és a globális kihívásokra kidolgozott megoldások létrehozásának és terjesztésének támogatása;

+ az uniós szakpolitikák kidolgozására, támogatására és végrehajtására gyakorolt hatás erősítése;

* az innováció minden formájának elömozdítása, az innovatív megoldások piaci bevezetésének erősítése;

* a program megvalósításának optimalizálása, hatásának növelése.

Az új keretprogram kidolgozása során a Bizottság számos értékelést és javaslatot vett figyelembe, így különösen támaszkodott a korábbi programokban pályázók, kedvezményezettek visszajelzéseire, e támogatások utólagos, továbbá a folyamatban lévő, H2020 keretprogram félidős értékeléseinek megállapításaira, valamint független, külső, szakértői munkacsoportok véleményére. Mindezek alapján a Bizottság a következő alapelveket fogalmazta meg a jövőre vonatkozóan:

1. Javasolt fenntartani a korábbi programban alkalmazott hárompilléres szerkezetet, valamint az egyszerüsített finanszírozási modellt. Folytatódik a költség-visszatérítési rendszer egyszerübbé tétele, különösen a személyi költségek esetében.

2. A H2020 szabályozása is nagy hangsúlyt fektetett a kedvezményezettek belső számviteli gyakorlatának elfogadására; amit a következő 7 évben még szélesebb körben terjesztenek ki, különösen a belső számlázás és szolgáltatások tekintetében.

3. A kedvezményezettek sok esetben nemcsak a kutatási és innovációs keretprogramból részesülnek támogatásban, hanem más, uniós pályázatokból (pl. Strukturális Alapok) is. A több programban kedvezményezettek ellenőrzési terheit a Bizottság csökkenteni kívánja a jövőben a korábbi ellenörzési eredmények fokozott átvétele révén.

4. A jelenlegi keretprogramban kísérleti jelleggel alkalmazott, ún. kiválósági pecsét címet elnyerő vállalkozások támogatást kaphatnak más, uniós programokból, így a Kohéziós és Strukturális Alapokból vagy Európai Mezőgazdasági Vidékfejlesztési Alapból. A kiválósági pecsét egy minőségi védjegy, amelyet olyan kkv-k kaphattak, amelyek által benyújtott projektjavaslatok 
teljesítették az elbírálásukra vonatkozó, valamennyi kiválasztási kritériumot (1. kiválóság, várható hatás, a végrehajtás minősége és hatékonysága), azonban az adott felhívásban rendelkezésre álló források szükössége miatt nem részesülhettek finanszírozásban. A pecsét igazolja a tervezett projekt kiváló minőségét, így a megvalósító könnyebben találhat másik (regionális, nemzeti, magán- vagy közszektorbeli) finanszírozási forrást. ${ }^{3}$

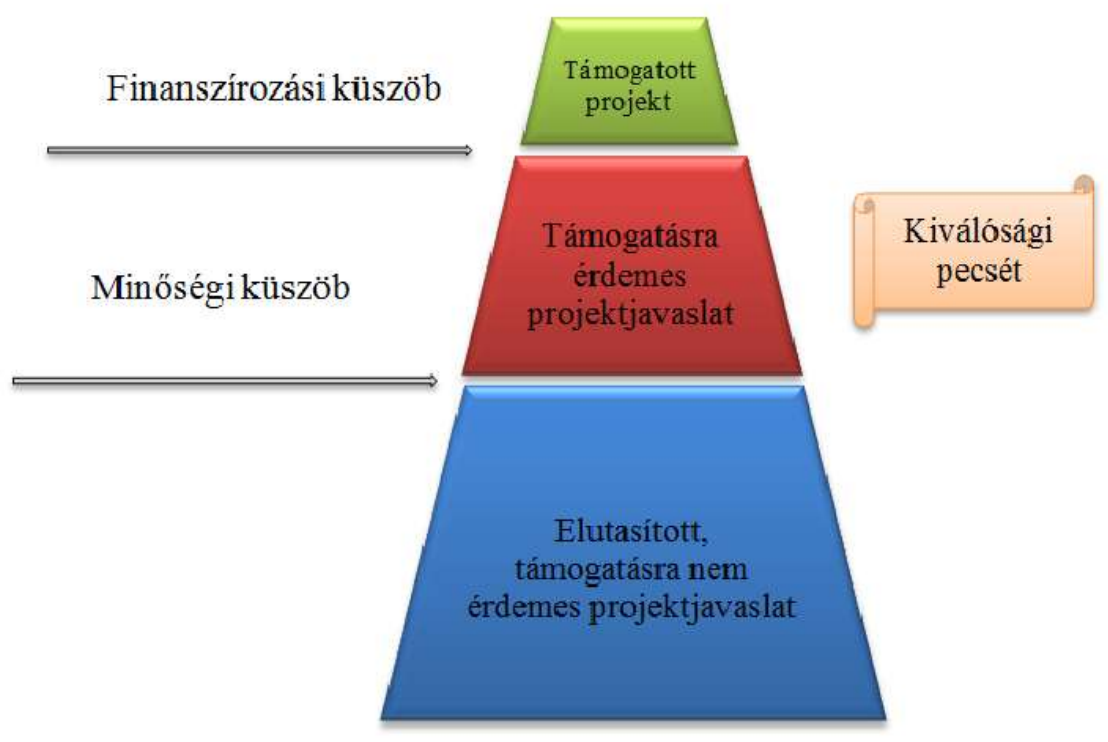

1. ábra. Kiválósági pecsét

5. Az új keretprogramban a Bizottság az egyszerüsített költség-elszámolási módszerek fokozott alkalmazását javasolja, különös tekintettel az egyösszegű átalányon alapuló projektfinanszírozásra az érintett területeken.

6. Az új program végrehajtása is egyszerüsödik tovább a tervek szerint, ami érinteni fogja az eljárásokat, a dokumentációkat, a támogató szolgáltatásokat és az informatikai rendszereket. Kimondott cél a pályázók adminisztratív terheinek csökkentése és a támogatások odaítélési folyamatának gyorsítása.

\section{Az Európai Horizont keretprogram szerkezete}

Az Európai Parlament és a Tanács 2019. március 19-én egyetértési megállapodást írt alá az új keretprogramról. Maradtak még nyitott kérdések, így a költségvetés, a szinergiák és a harmadik országokkal való együttmüködés. Természetesen e kérdések, így különösen az Európai Horizont költségvetése a többéves pénzügyi keretről szóló tárgyalások eredményének függvényében kerülnek elfogadásra. A megállapodást követően, a Bizottság megkezdte a program végrehajtásának előkészítését.

Az új keretprogram javasolt felépítését a 2. ábra mutatja.

http://www.kaleidoscopehistory.hu

Szitáné dr. Kazai Ágnes 


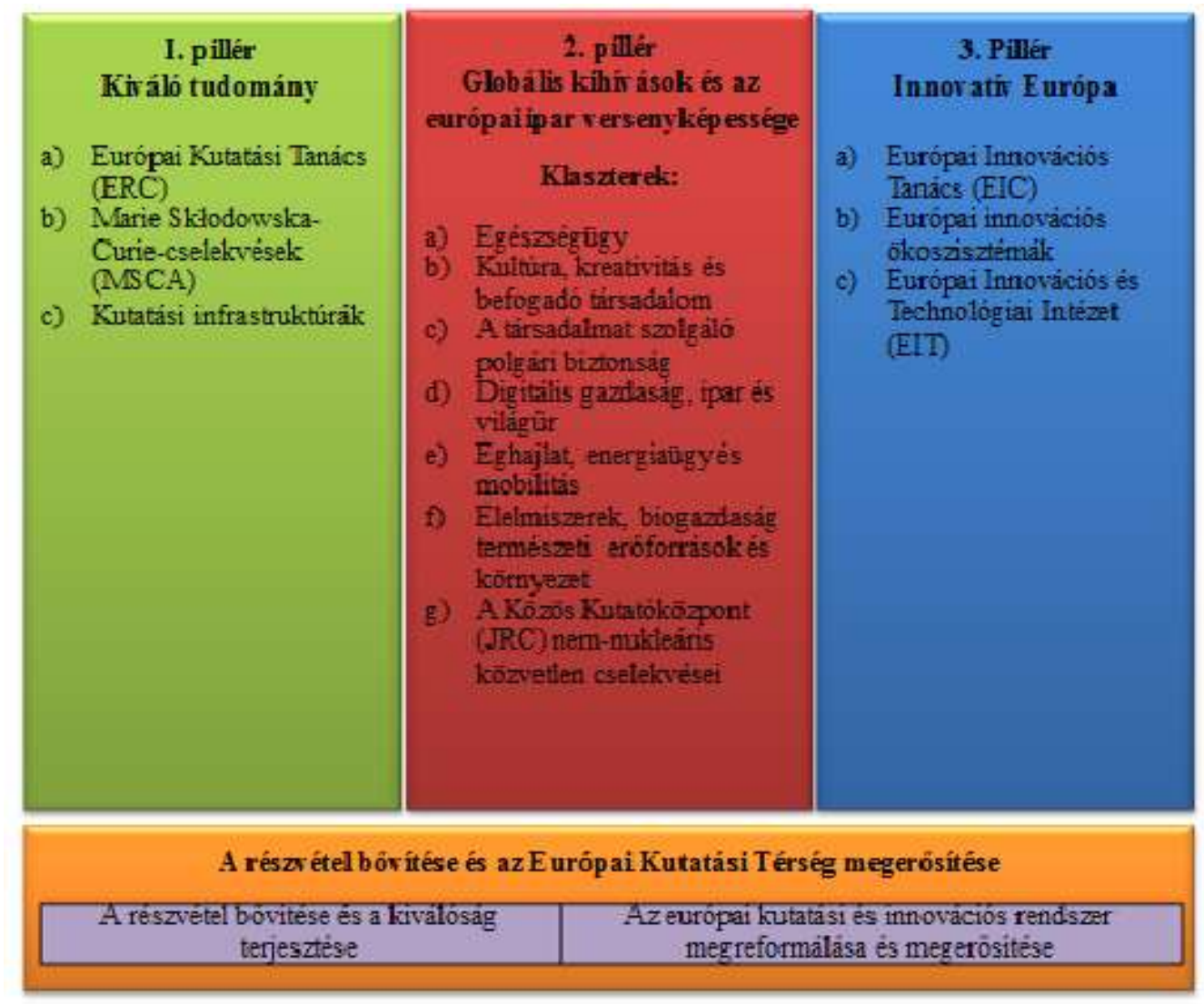

2. ábra. Az Európai Horizont szerkezete

Az Európai Horizont program alapját tehát - az elődjéhez hasonlóan - a következő három, egymást kiegészítő pilléren biztosítja.

1. A Kiváló tudomány elnevezésű első pillér a legmagasabb színvonalú tudományos alaptevékenységek támogatását tűzi ki célul. Európa döntéshozóinak várakozása szerint e pillér keretében nyújtott támogatások hozzájárulnak majd az Unió tudományos vezető szerepének erősítéséhez.

2. A Globális kihívások és európai ipari versenyképesség nevü második pillér napjaink legnagyobb társadalmi kihívásaira választ adó és az ipari technológiák fejlesztését célzó kutatás finanszírozásához járul hozzá a kulcsfontosságú területeken. E szakterületeken zajló kutatási és innovációs $(\mathrm{K}+\mathrm{I})$ tevékenységeket korlátozott számú, kutatási küldetések és partnerségek fogják kiegészíteni (ezekről még a későbbiekben lesz szó).

3. A harmadik pillér az Innovatív Európa elnevezést kapta, jelezve az Európai Horizont program korábbinál jelentősebb elköteleződését az innováció erősítése mellett.

A három pillért 2021-től is kiegészítik azok az intézkedések, amelyek a programban való részvétel kiszélesitését és az Európai Kutatási Térség megerősitését szolgálják, egyebek mellett azon tagországok célzott támogatásával, amelyek K+I-teljesítménye elmarad a fejlettebb országokétól.

Az egyes pillérek révén megvalósítani kívánt célokat a 3. ábra foglalja össze. 


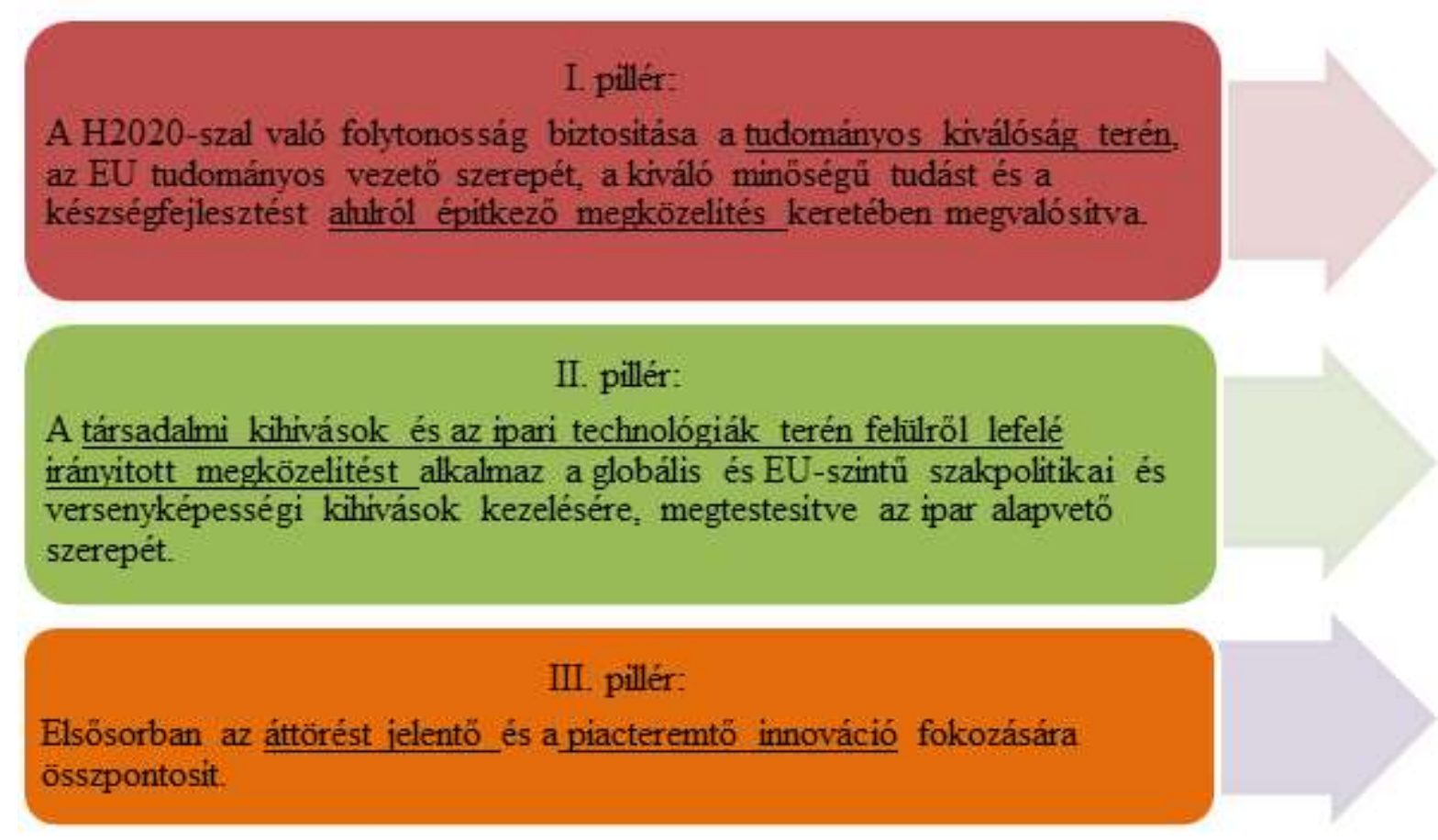

3. ábra. Az egyes pillérek legfontosabb jellemzői

\section{Az Európai Horizont keretprogram költségvetése}

Mint már a fentiekben szó volt róla, a program költségvetéséről csak a 2021-2027-es időszakra vonatkozó, többéves pénzügyi keret jóváhagyásakor születik végleges döntés. A Bizottság 2018-ban minden korábbinál nagyobb összeget javasolt az Európai Horizont tevékenységeinek támogatására. A következőkben leírtak e bizottsági javaslat részleteibe vezetik be az olvasót.

A 4. ábra a Bizottság teljes (94,1 Mrd € összegü) költségvetési javaslatát, valamint ennek az egyes pillérek közötti megoszlását mutatja be. 


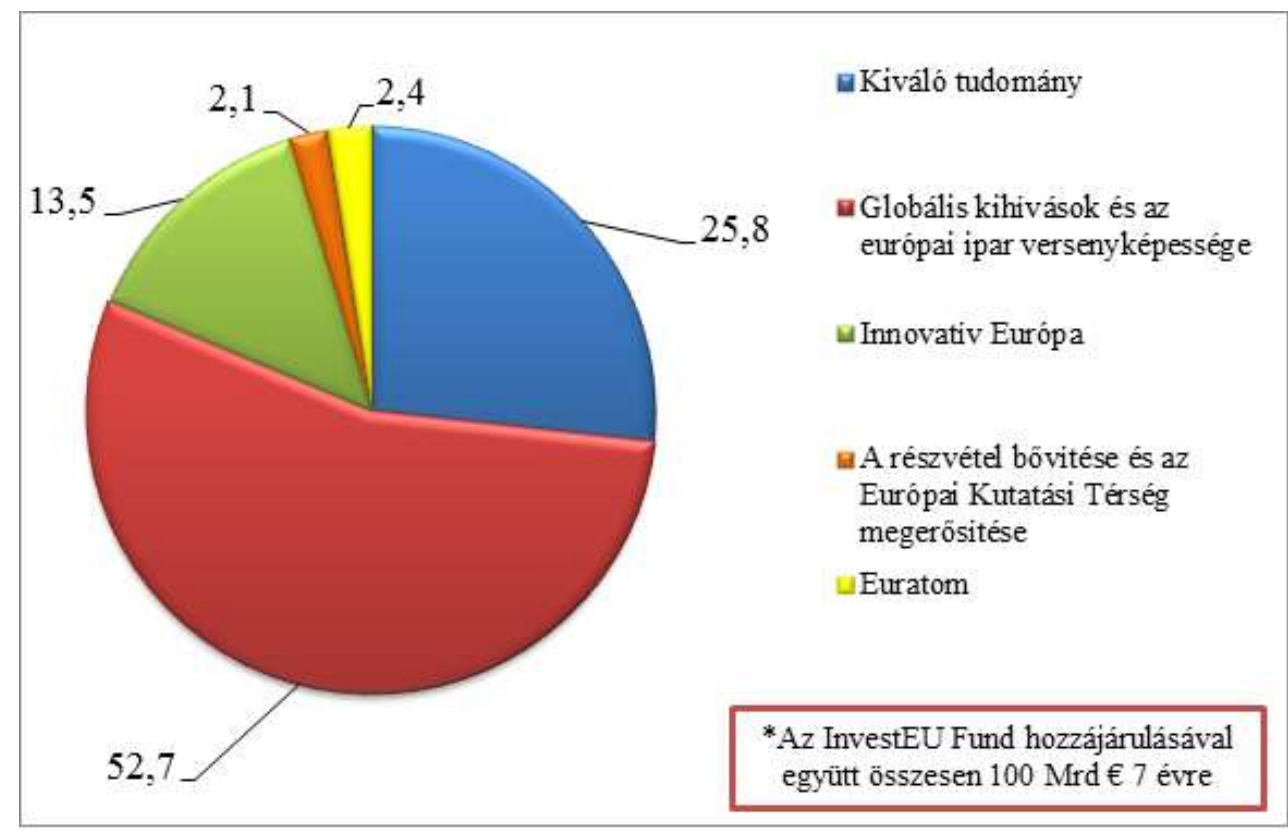

4. ábra. Az Európai Horizont (2021-2027) költségvetése (Mrd €, folyó áron)

A javasolt költségvetési összeg egyes pilléreken belüli indikatív megoszlását a következő ábrák szemléltetik.

\section{Európai Kutatási Tanács: 16,6 Mrd $€$}

Cél A legjobb kutatók és munkacsoportjaik számára vonzó és rugalmas támogatás nyujitása.

Beavatkozási terïletek felderitố kutatások

\section{Marie Sklodowska-Curie-cselekvések: 6,8 Mrd €}

Cél: Kutatói ösztöndijak és csereprogramok a kutatók ủj ismeretekkel és készségekkel való felvértezése érdekében.

Beavatkozási területek: határokon, ágazatokon és tudományágakon átnyúló kutatói mobilitás; kutatói képzések; tájékoztatási tevékenységek

\section{Kutatási infrastruktúrák: 2,4 Mrd $€$}

Cél Világszinvonalú, integrált, fenntartható és összekapcsolt kutatási infrastrukturra biztositása a legkiválóbb kutatók számára.

Beavatkozási területek az európai kutatási infrastruktúrák kōrnyezetének megszilárditása: az infrastruktúrák megnyitása, integrálása és ósszekapcsolása

\section{5. ábra. I. pillér - Kiváló tudomány (25,8 Mrd €)}

http://www.kaleidoscopehistory.hu

Szitáné dr. Kazai Ágnes 


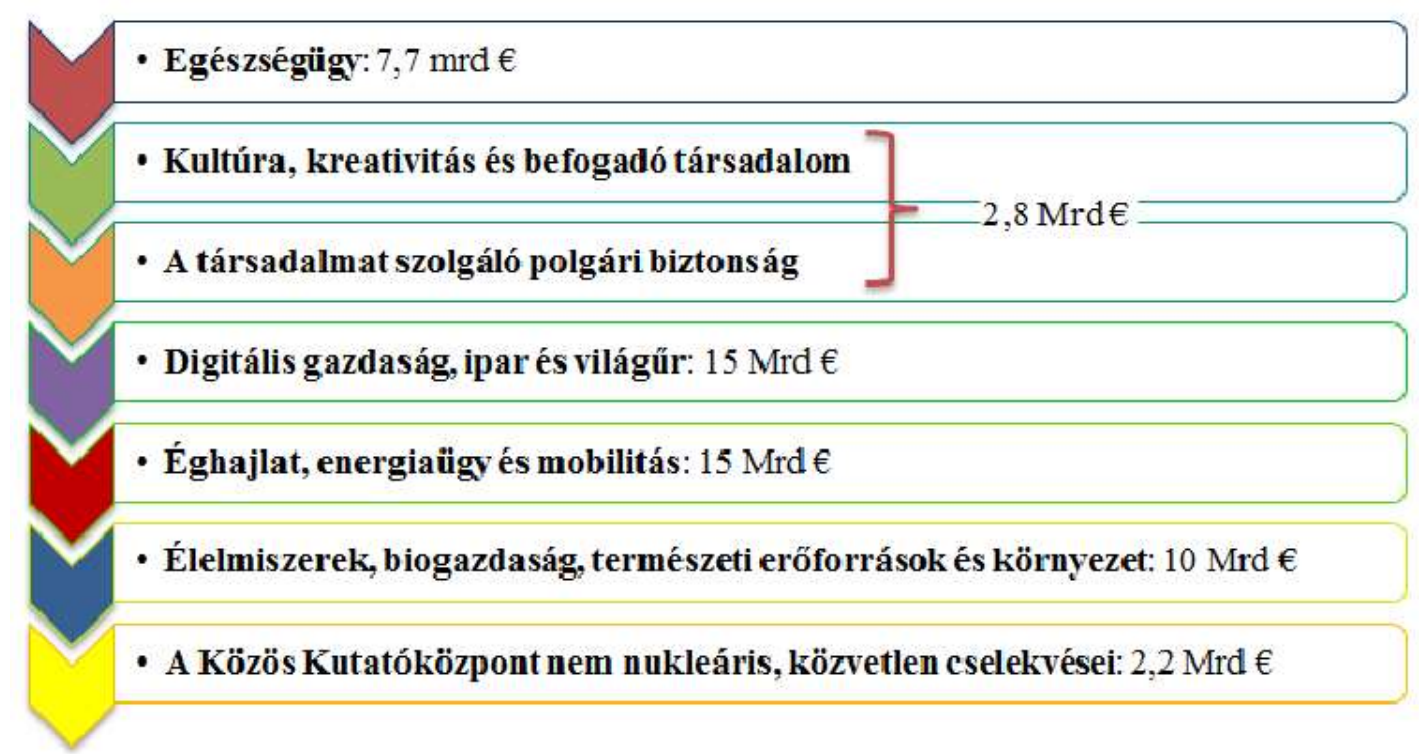

6. ábra. II. pillér - Globális kihívások és az európai ipar versenyképessége (52,7 Mrd €)

A Bizottság eredeti, 2018. évi javaslata 5 klasztert és a Közös Kutatóközpont nem-nukleáris akcióit nevesítette. A javaslat benyújtását követő egyeztetések és megállapodások alapján 6-ra emelkedett a klaszterek száma, és egyes esetében változott elnevezésük és tartalmuk. Mindebből következően, a fenti ábra a II. pilléren belüli, indikatív pénzügyi megoszlás ismertetésénél a módosult elnevezéseket, de az eredeti bizottsági javaslat szerinti összegeket tartalmazza.

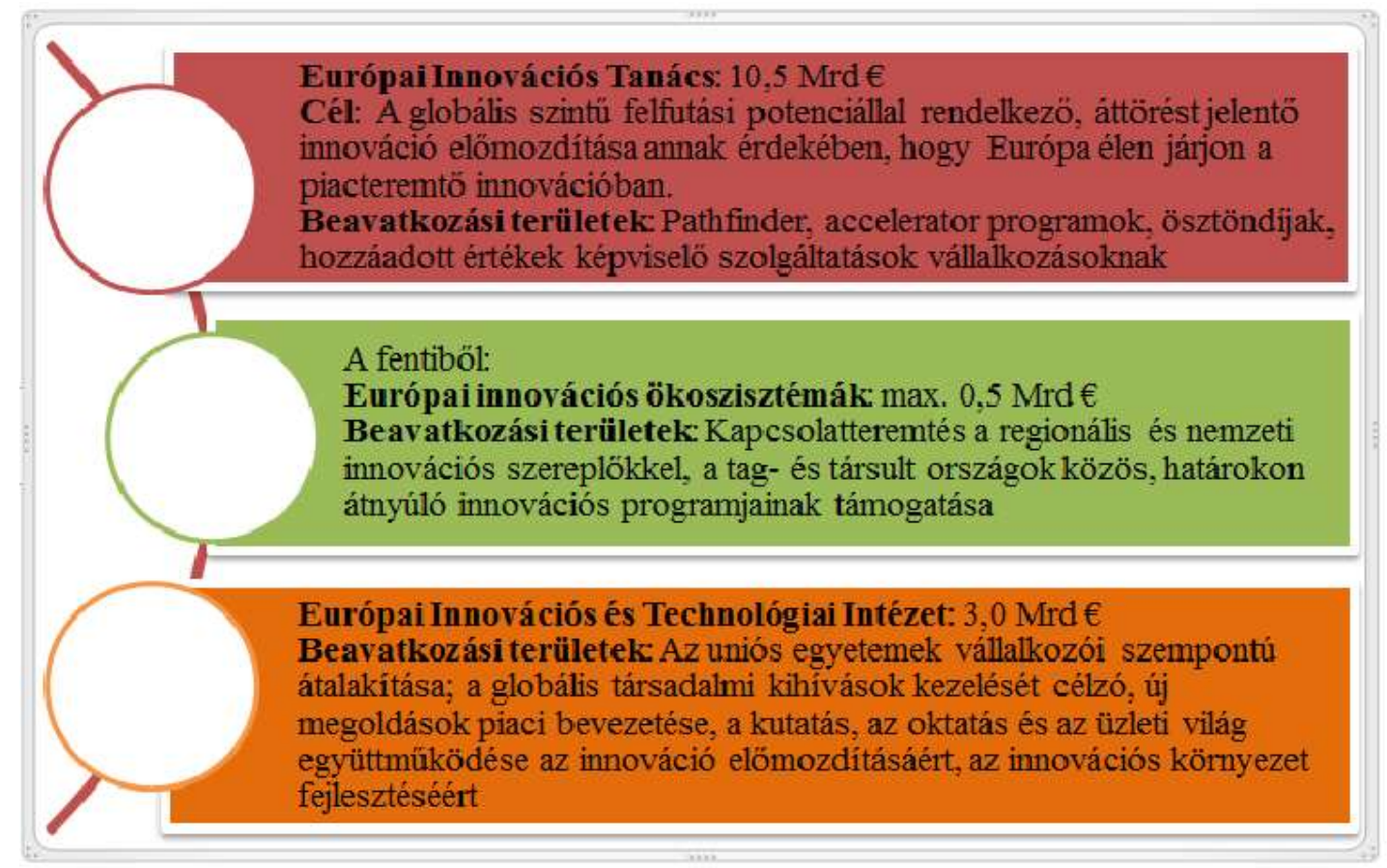

7. ábra. III. pillér - Innovatív Európa (13,5 Mrd €)

http://www.kaleidoscopehistory.hu

Szitáné dr. Kazai Ágnes 
Kaleidoscope

Az Európai Horizont három pillérét az Európai Kutatási Térség (EKT) megerôsítésére irányuló támogatások egészítik ki. E beavatkozások célja a kutatás és innováció területén kevésbé jól teljesítő országok tudományos potenciáljának minél teljesebb kiaknázása, ezek közelítése az uniós kiválósági normákhoz. E támogatási formákat jórészt már megismerhettük a H2020 programban.

Néhány magyar intézmény - köztük a Semmelweis Egyetem is - eredményesen pályázott az e körbe tartozó felhívásokra, és a nyertes projektek megvalósítása folyamatban van. Az EKT megerösítését célozzák az európai $\mathrm{K}+\mathrm{I}-$ rendszer megreformálására, javítására irányuló tevékenységek is.

E beavatkozások jelentőségét jelzi az a tény is, hogy az Európai Tanács és a Parlament közötti egyetértési megállapodás értelmében a részvétel bővítése és a kiválóság terjesztése elnevezésű részen belüli támogatásokra az Európai Horizont programra szánt teljes költségvetés legalább 3,3\%-át kell fordítani. ${ }^{4}$ E finanszírozás elsősorban az alacsonyabb K+I-teljesítményű országok - köztük Magyarország pályázóinak javát fogja szolgálni.

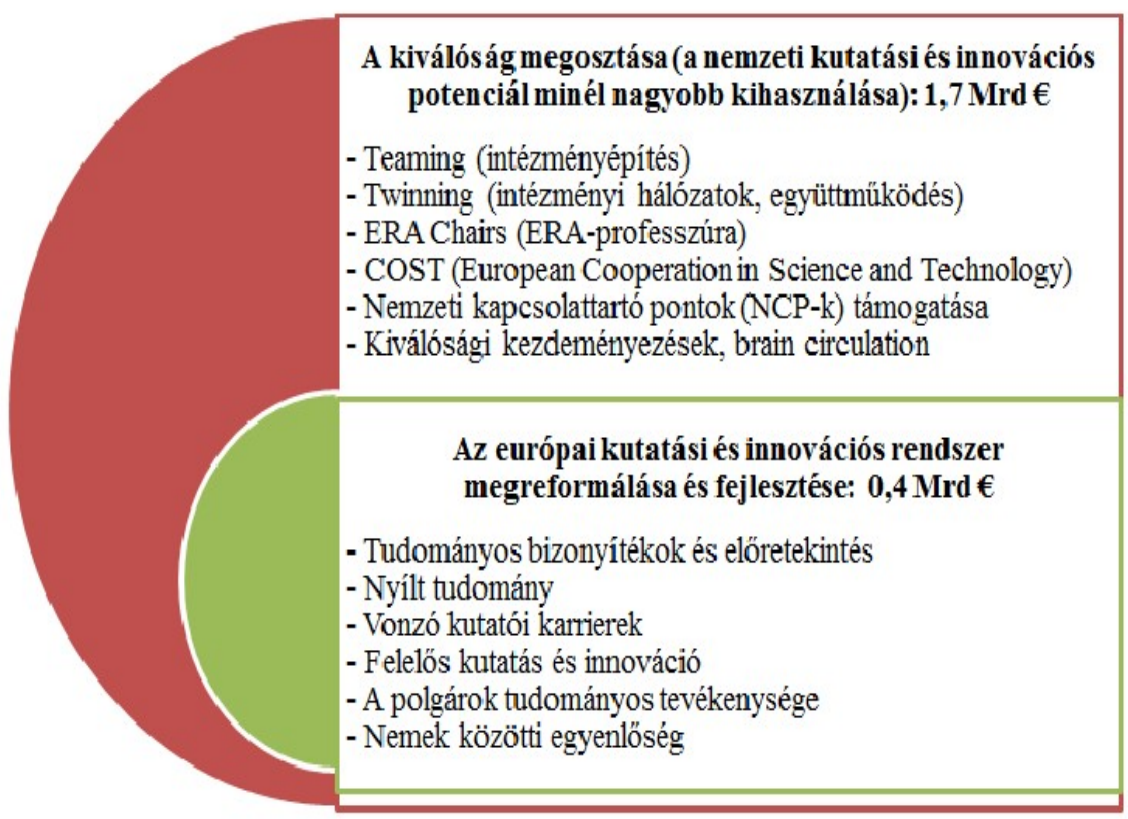

8. ábra. Az Európai Kutatási Térség megerősítése (2,1 Mrd €)

Az Európai Horizont keretprogram jogalkotási csomagjának részét képezi az Euratom kutatási és képzési programra irányuló javaslat is, amely a nukleáris energia különböző európai alkalmazásainak kulcsfontosságú kérdésével foglalkozik.

A bizottsági tervezet leszögezi, hogy „a nukleáris energia energiatermelési és nem energiatermelési célú alkalmazásainak az európai lakosság javára való felhasználásához hosszú távú eröfeszitések szükségesek a biztonsági és védelmi kockázatok csökkentése, valamint a biztonságos nukleáris technológiák és az optimális sugárvédelem fejlesztésének támogatása érdekében".

A testület 7 évre összesen 2,4 Mrd €-t irányzott elő a programra; ugyanakkor a bizottsági javaslat 5 évre szól, mivel az Euratom-szerződés 7. cikke ezt az időtartamot határozza meg.

http://www.kaleidoscopehistory.hu

Szitáné dr. Kazai Ágnes 


\section{Célkitüzés}

A nukleáris védelmet és biztonságot fenyegető kockázatok csökkentését szolgáló kutatási és képzési tevékenységek; biztonságos nukleáris technológiák és optimális sugárzásvédelem fejlesztése.

\section{A legfontosabb új elemek}

Fokozott figyelem a sugárzásnem energiatermelési célú (orvosi, ipari, ủrkutatási) alkalmazására.

* Mobilitási lehetőségek megnyitása a nukleáris kutatók számára a Marie Skłodow ska-Curie-cselekvésekben valórészvételük révén.

* Egyszerüsítés: az egyedi célkitüzések számának a jelenlegi 14-rö1 4-re csökkentése, köztük (a JRC által végrehajtott) közvetlen és közvetett intézkedésekkel.

9. ábra. Az Euratom kutatási és képzési program (2021-2025)

\section{Az Európai Horizont legfontosabb újdonságai és horizontális elemei}

Az Európai Horizont program legfontosabb újdonságait a következőkben foglaljuk össze:

\section{Az Európai Innovációs Tanács}

Az Európai Innovációs Tanács (EIC) létrehozásáról már korábban döntés született; az előkészítésre 2017 januárjában vezető innovátorokból álló munkacsoport alakult. A csoport által összeállított jelentést egy évvel később fogadták el. ${ }^{6}$

Az EIC új megközelítést vezetett be az innováció támogatásában. Az innovációs ötleteket bármikor fogadták, és a pályázatok elbírálását felgyorsították; a támogatásról szóló döntést 4 hónapon belül meghozták. A 2018. évi 778 millió $€$ költségvetés terhére 450 millió $€$ összegü támogatásról döntöttek. A következő 2 évben emelték az EIC rendelkezésére álló büdzsét.

Az EIC legfontosabb küldetése, hogy az európai innováció katalizátora legyen. Az innovációs tevékenységeket folytatókat kétféle finanszírozási eszközzel kívánják támogatni:

* A Pathfinder programban a forradalmian új, áttörést jelentő koncepciók működőképességének igazolásához és a korai fázisú fejlesztéshez nyerhetnek el akár 4 millió $€$-t is a nemzetközi konzorciumban megvalósított projektek 100\%-os támogatási intenzitás alkalmazásával.

* Az Akcelerator program az önállóan pályázó kkv-k, start-upok, vállalkozók bármilyen témában megvalósuló, piacközeli innovációinak támogatására nyújthat 2,5 millió € összegű támogatást. Itt az elszámolható költségek 70\%-ának finanszírozására számíthatnak a pályázók. 
Pathfinder-program: támogatás a technológiafejlesztés kezdeti szakaszától a kereskedelmi hasznositást. megelözö szakaszig
Akcelerátor program:

támogatás és vegyes finanszírazás a kereskedelmi hasznositást megelözó szakasztól a piaci bevezetési és növekedési szakaszig
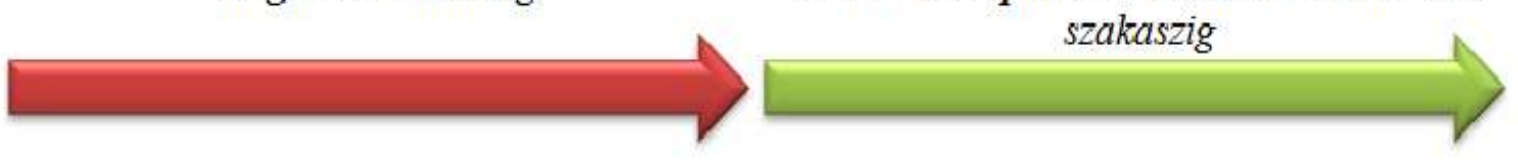

10. ábra. A Pathfinder és az Akcelerátor program támogatási időszakai

\section{K+I-küldetések egész Európára kiterjedően}

A II. pillér keretében megjelenő pályázati felhívások mellett korlátozott számú, kiemelkedő jelentőségű, hatásorientált, ún. K+I-küldetés bevezetését irányozta elő a Bizottság, amelyek kidolgozásában számítanak a tagállamok, az Európai Parlament, az érdekelt felek és a polgárok részvételére.

A célok ambiciózusak, a küldetések megvalósítása határidőhöz kötött, egyértelmű szándék a nyilvánosság megszólítása és bevonása. E küldetések nagy jelentőséggel bírnak az európai polgárok széles köre számára. Ugyan a küldetéseket a II. pilléren belül tervezik, sikerükhöz hozzájárulnak a másik két pillér cselekvései is. A küldetések tehát

uniós hozzáadott értékkel rendelkeznek, és segítik az EU prioritásainak megvalósítását;

merészek és ösztönzőek, széles körü társadalmi vagy gazdasági hatással bírnak;

világos irányt határoznak meg, célhoz és időhöz kötöttek, eredményeik mérhetők;

ambiciózus, de egyben valóságos K+I-tevékenységek köré szerveződnek;

több tudományágban, ágazatban is cselekvésre ösztönöznek;

az alulról építkező megoldásokra is nyitottak. 


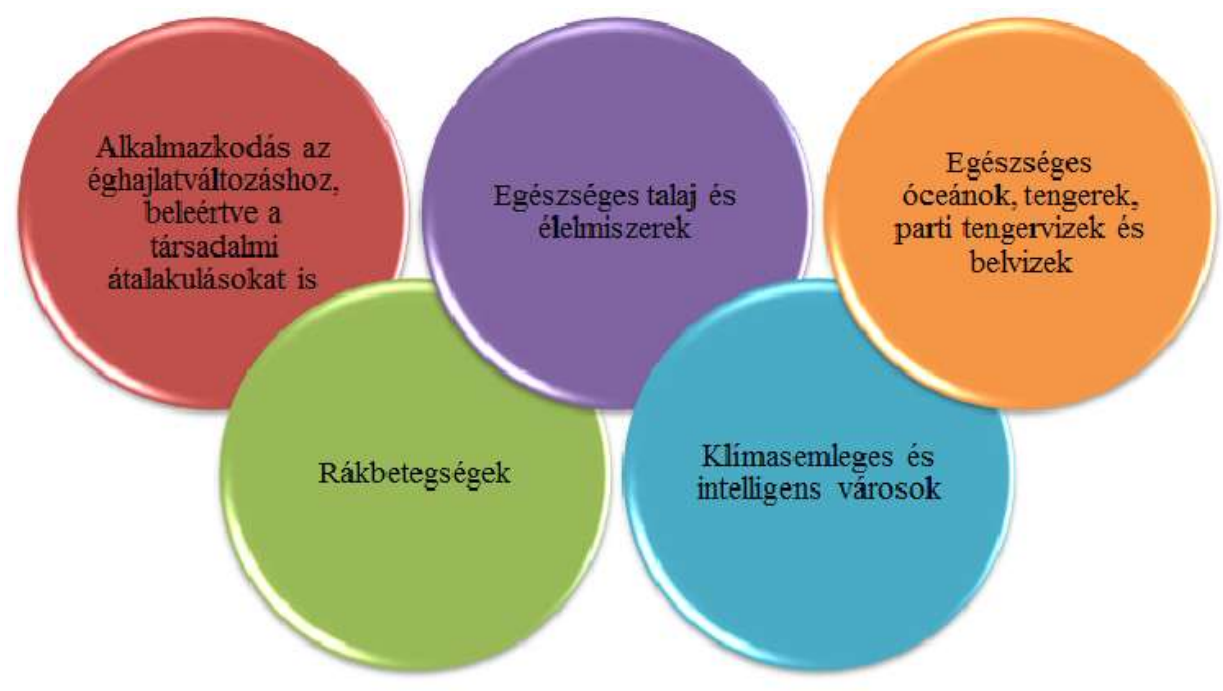

11. ábra. A K+I-küldetési területek az Európai Horizont programban

\section{Az európai partnerségek megújítása}

Az Európai Horizont célul tűzi ki az európai partnerségek ésszerüsítését. E törekvés jegyében a program társfinanszírozás formájában - támogatni fogja az uniós tagállamokkal, a magánszektorral, alapítványokkal, a civil társadalommal kialakított együttmüködéseket. A cél nyilvánvaló: a rendelkezésre álló forrásokat az elfogadott szakpolitikai prioritások érdekében a leghatékonyabban és leghatásosabban kívánja az Unió felhasználni, elkerülve a párhuzamosságokat a globális kihívásokra való válaszadás és az ipari modernizáció érdekében. Az együttmüködés körébe bevonják a Kohéziós és Strukturális Alapokat, az Európai Védelmi Alapot, a Digitális Európa programot, az Európai Hálózatfinanszírozási Eszközt, valamint az ITER nemzetközi fúziósenergia-projektet. Az Európai Horizontra vonatkozó bizottsági javaslat 3 partnerségi típust nevesít. 


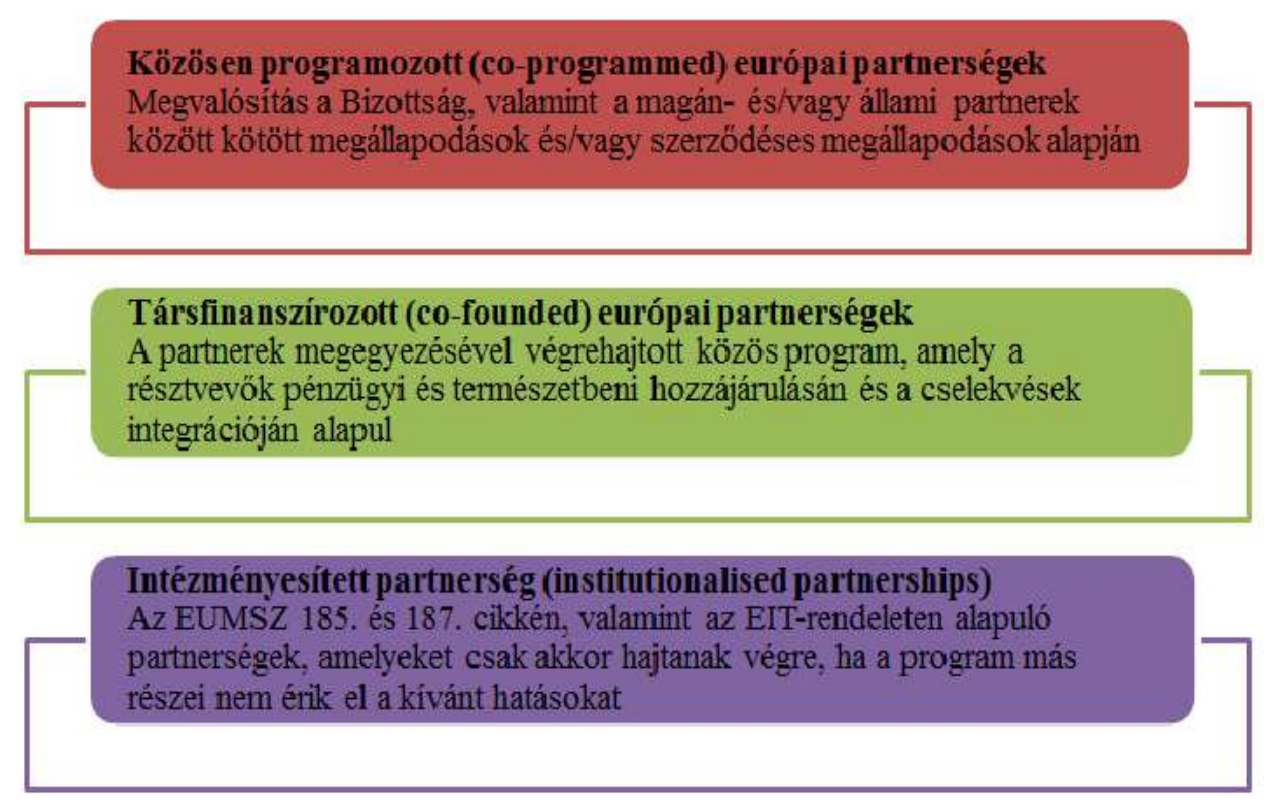

12. ábra. Partnerségek az Európai Horizont programban

Az intézményesített partnerség lehetséges beavatkozási területei:

* Egészségügyi innovációk

* Kulcsfontosságú digitális és alaptechnológiák

* Fenntartható, bioalapú megoldások

* Európai légi forgalom, légi és vasúti közlekedés

* Metrológia

* Hidrogéntechnológiák és fenntartható energia - tárolási technológiák

* Tiszta, összekapcsolt mobilitás

* Innovatív kis-és középvállalkozások

\section{Nyílt tudomány}

A nyílt tudomány elve az Európai Horizont működési módjává lép elő. A megelőző keretprogramban megismert politikán túllépve, nyílt hozzáférést ír elő a publikációkhoz és az adatokhoz (meghatározott mentesülési lehetőségekkel), valamint a kutatásiadat-kezelési tervekhez.

* A publikációkhoz történő, kötelező, nyílt hozzáférés keretében a kedvezményezetteknek a szellemitulajdon-jogok fenntartása mellett biztosítaniuk kell a nyílt hozzáférésre vonatkozó kötelezettségek teljesítését.

* A kutatási adatokhoz való nyílt hozzáférés biztosításának alapelve ,a szükséges zártság melletti lehető legnagyobb mértékü nyitottság”. A program támogatni fogja a FAIR (kereshető, hozzáférhető, átjárható és újrafelhasználható) adatok széles körü felhasználását, valamint azokat a tevékenységeket, amelyek bővítik a kutatók szakismereteit.

* A kutatás feddhetetlensége és a polgárok tudományos tevékenysége központi szerepet játszik, hasonlóképp a kutatásértékelési indikátorok új generációjának kidolgozásához.

http://www.kaleidoscopehistory.hu

Szitáné dr. Kazai Ágnes 
* Az ambiciózus tervek között szerepel az európai, nyílt tudományosadat-felhő megvalósítása, az európai adattér erősítése.

\section{A részvétel bővítése és a kiválóság terjesztése}

A részvétel szélesítésére és a kiválóság terjesztésére irányuló intézkedések jó részét már megismerhettük a Horizont 2020-ban. E cselekvések nagy hangsúlyt kapnak a következö 7 éves periódusban is. Fenntartásukat, illetve bővítésüket az indokolja, hogy az érintett tagállamok (EU 13-országok, amelyek kutatási és innovációs teljesítménye elmarad a többiekétől) pályázati tevékenységükben továbbra sem olyan sikeresek, mint a régiek. Kevés koordinátori pozíciót sikerül pályázóiknak betölteniük, a támogatott projektek számát és az elnyert finanszírozás összegét illetően háttérbe szorulnak a fejlettebb országokkal szemben. A H2020-ban bevezetett, kifejezetten számukra rendelkezésre álló lehetőségek nem hozták meg a kívánt eredményt, azaz ezen államok $\mathrm{K}+\mathrm{I}$-területen tapasztalt elmaradása lényegesen nem változott. A következő keretprogramban ezért indokolt az intézkedések és a rájuk szánt finanszírozás (a teljes költségvetés min. 3,3\%-a) bővítése.

Nemzeti kapssolattartó pontok (NCP-k) támogatása

15 tagállam és 9 legkülső régió koordinátori tevékenységének elősegítése

A részvétel elismerése

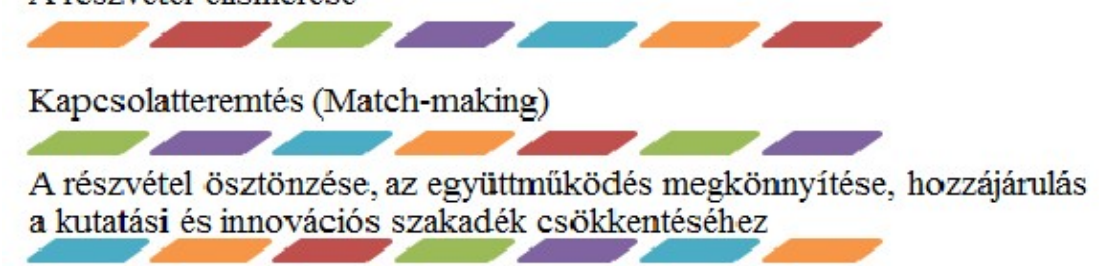

Hop-on scheme (létező, nyertes konzorciumhoz való csatlakozás - új elem)

Teaming, Twinning, ERA-Chairs, COST

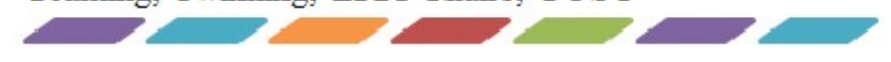

Kiválósági kezdeményezések, brain circulation

\section{3. ábra. A részvétel bővítése és a kiválóság terjesztése érdekében tervezett intézkedések}

A részvétel szélesítése érdekében korábbról bevezetett programok folytatódnak, illetve megújulnak a következők szerint. ${ }^{7}$

\section{Teaming}

A program a már meglévő vagy újonnan alakuló kiválósági központok támogatását tüzi ki célul az alacsonyabb $\mathrm{K}+\mathrm{I}$-teljesítményt mutató országokban. A teaming-folyamatban továbbra is részt vesz Európa valamelyik, nemzetközi hírü kutatási intézménye. 
\# Twinning

A tervezett intézkedések erösíteni kívánják egy alacsonyabb K+I-teljesítményű ország feltörekvő, felsőoktatási vagy kutatási intézményének meghatározott kutatási területét, összekapcsolva e szervezetet legalább 2, nemzetközi szinten vezető partnerintézménnyel. Az együttmüködésnek növelnie kell a csatlakozó intézmények tudományos és technológiai kapacitását, és szélesítenie kell az intézmények és azok személyi állománya kutatási profilját.

* ERA Chairs (ERA-professzúra)

A program keretében a kevésbé fejlett régiók ígéretes kutató vagy felsőoktatási szervezetei kaphatnak támogatást nemzetközi szintü, kiváló kutatók alkalmazásához, akik - saját kutatócsoportjukat létrehozva - segíteni fogják majd az intézményeket a hosszú távon fenntartható kiválóság elérésében.

A fentiek mellett további két, kiegészítő akció nyújt majd közvetlen támogatást az érintett országoknak:

* Horizon 2020 Policy Support Facility (PSF)

Ez az akció a tagországok kutatási és innovációs politikáinak fejlesztéséhez ad „személyre szabott” segítséget, adatbázisok, help-deskek kialakításán, valamint disszeminációs tevékenységek megvalósításán keresztül.

* COST

COST (The European Cooperation in Science and Technology, Európai Tudományos és Technológiai Együttműködés) a kutatási hálózatok létrehozását támogató szervezet. A jelenleg 38 országot tömörítő COST-együttműködést 1971-ben hozta létre 19 ország, azért, hogy európai szinten összehangolják a nemzeti forrásokból támogatott kutatásokat. Magyarország 1991. óta tagja az együttműködésnek, amelyet az Európai Bizottság támogat - jelenleg a H2020 program keretében. Az ún. COST-akciókban elsősorban felsőoktatási intézmények, kutatóintézetek és kisebb mértékben iparvállalatok vesznek részt. A kutatási hálózatok, illetve tevékenységek nyitottak, alulról felfelé építkezők és interdiszciplináris jellegüek. Az eddigi tapasztaltok szerint, a COST-akciókban átlagosan 50 partner vesz részt, 130 ezer $€$-s éves költségvetés és 4 éves futamidő mellett. A program rendelkezésre áll a nem COST-tagállamok számára is.

\section{InvestEU a kutatásért és az innovációért}

¿ z Európai Bizottság a következő 7 évre vonatkozó költségvetési tervben javasolja az InvestEU program létrehozását, amely egy fedél alá hozza az uniós költségvetésből hitelek és garanciák formájában nyújtott finanszírozásokat.

A program összefogja a jelenleg elérhető finanszírozási lehetőségek sokaságát, lendületet adva a munkahelyteremtésnek, a beruházásoknak és az innovációnak a - becslések szerint -650 Mrd $€$ további beruházás mozgósításával. 
Fenntartható infrastruktuira (n)

Kutatás, innováció és digitalizáció

\section{Támogatható területek:} fenntartható energia, digitális hálózatok, közlekedés, körforgásos gazdaság, víz-, hulladék- és egyéb kömyezeti infrastruktúra

\section{Támogatható területek:}

kutatás és innováció, a kutatási eredmények piaci bevezetése, az ipar digitalizálása, nagyobb innovatív vállalkozások bövítése, $\mathrm{I}$ mesterséges intelligencia
Kis-és középvállalkozások köepvallalkozasok

Szociális beruházás és készségfejlesztés

\section{Támogatható területek:}

kkv-k, kisebb v. közepes piaci tökeértékü vállalkozások finanszírozáshoz való hozzáférésének elösegítẻse

\section{Támogatható területek:}

készségek, oktatás, képzés, szociális lakások, iskolák, egyetemek, kórházak, szociális innováció, egészségügyi ellátás, tartós ápolás, akadálymentesítés, mikrofinanszírozás, szociális vállalkozások, menekültek és kiszolgáltatott helyzetben lévök integrációja

\section{4. ábra. Az InvestEU által támogatott szakterületetek ${ }^{8}$}

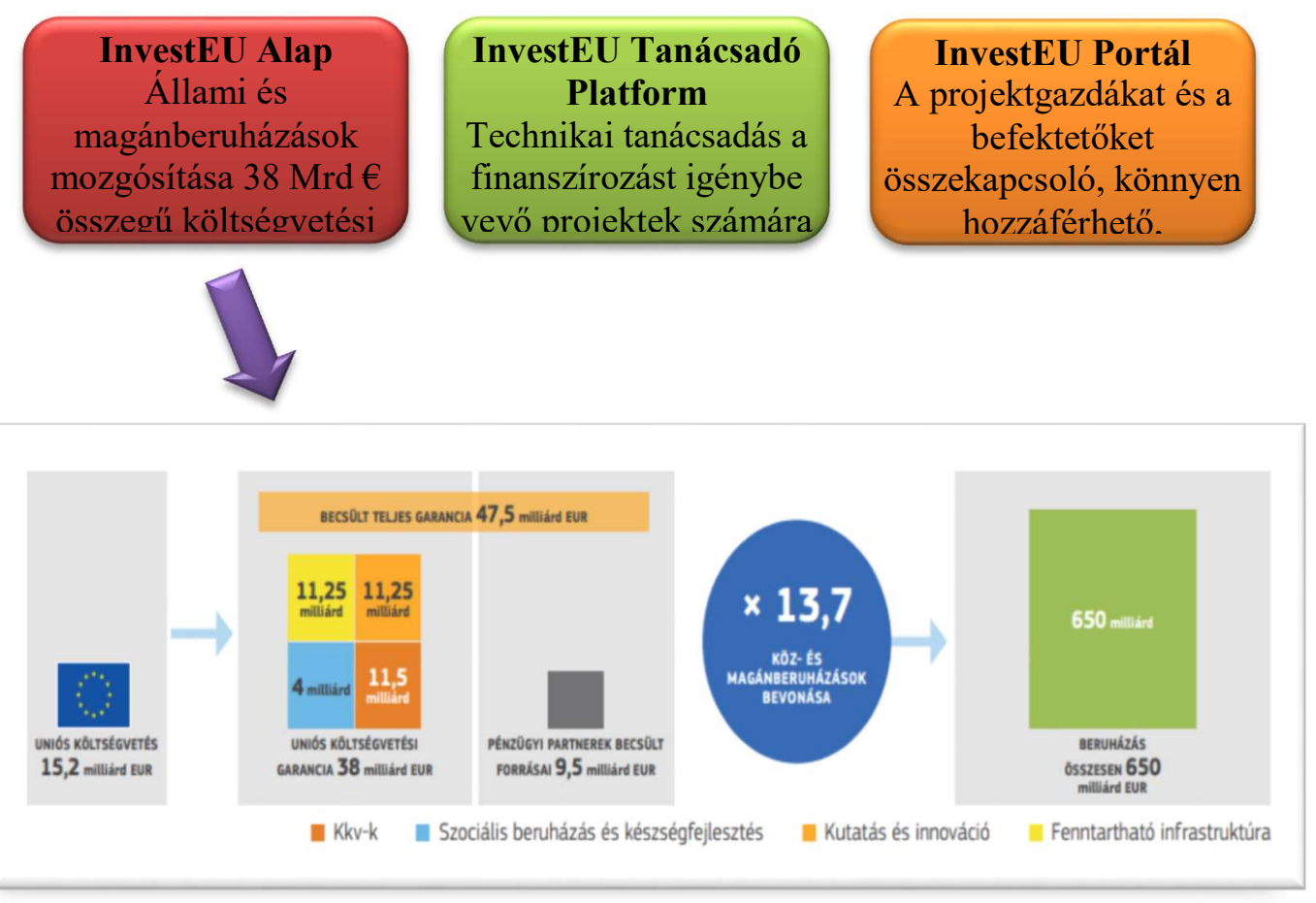

http://www.kaleidoscopehistory.hu

Szitáné dr. Kazai Ágnes 
Kaleidoscope süvelődés-, Tudomány- és Orvostörténeti Folyóirat
Journal of History of Culture, Science and Medicine

DOI: $\underline{10.17107 / K H .2020 .20 .262-279}$

\section{5-16. ábra. Az InvestEU program részei ${ }^{9}$ és az InvestEU Alap müködése}

\section{A további egyszerüsítést célzó rendelkezések}

A Horizont 2020 keretprogram jelentős rendelkezéseket léptetett életbe a pályázási, szakmai megvalósítási, beszámolási és ellenőrzési tevékenységek könnyítése érdekében. Ahogy a fentiekben már szó volt róla, a következő időszak programjának kidolgozása során a Bizottság jelentős mértékben támaszkodott a külső értékelők, szakértők véleményére, valamint az Európa-szerte, illetve az érintett államokban - így Magyarországon is - lezajlott nemzeti konzultációk eredményeire. A megkérdezettek egyértelmüen síkra szálltak az eddigi intézkedések, eredmények megőrzésért, valamint az egyszerüsítés folytatásáért.

E vélemények figyelembevételével tett a Bizottság javaslatot a további szimplifikációra, amelynek néhány elemét már korábban említettük. Az alábbi leírás a legfontosabb egyszerüsítési elemeket foglalja össze. ${ }^{10}$

* A partnerségi rendszer egyszerüsítése: csak 3 partnerségtípus; világos kiválasztási és végrehajtási kritériumok.

* A jelenleg alkalmazott költség-visszatérítési rendszer további egyszerüsítése; ez leginkább a személyi költségekre vonatkozik.

* A kedvezményezettek bevett számviteli gyakorlatának szélesebb körü elfogadása, különösen a belső számlázás és szolgáltatások tekintetében.

* Az egyszerüsített költség-elszámolási módszerek fokozott alkalmazása, különös tekintettel az egyösszegü átalányon alapuló projektfinanszírozásra adott területeken.

* A több uniós finanszírozási programban részt vevő kedvezményezettek ellenőrzési terheinek csökkentése érdekében, a már lezajlott auditok eredményeinek figyelembevétele.

* A résztvevői garanciaalap (új nevén: kölcsönös biztosítási mechanizmus) kiterjesztése.

* A pályázatértékelési és -kiválasztási folyamat főbb elemeinek megtartása az Európai Horizont valamennyi alprogramjában. Szélesebb szakértői kör bevonása, beleértve a felhasználói csoportokat és a civil szervezeteket is.

* Küldetésalapú megközelítés alkalmazása, ami azt jelenti, hogy az egyes pályázatok szintjén vizsgált kiválóságon és hatáson túl az értékelés arra is kiterjed, hogy a kiváló pályázatok együttesen milyen portfóliót alkotnak.

* A vonzó finanszírozási forma, illetve a 100\% támogatási arány megtartása.

\footnotetext{
${ }^{1}$ Szitáné Kazai, Á.: Az európai kohéziós és innovációs politika jövője. Kaleidoscope 2012/4.

Letöltés: 2020.04.04.

URL https://doi.org/10.17107/KH.2012.4.255-266
} 
${ }^{2}$ Proposal for a REGULATION OF THE EUROPEAN PARLIAMENT AND OF THE COUNCIL establishing Horizon Europe - the Framework Programme for Research and Innovation, laying down its rules for participation and dissemination. Brussels, 7.6.2018 COM(2018) 435 final 2018/0224(COD)

Letöltés: 2020.04.04.

URL https://ec.europa.eu/commission/publications/research-and-innovation-including-horizon-europe-iter-andeuratom-legal-texts-and-factsheets en

${ }^{3}$ Seal of excellence. What it is, who can benefit, how to use it. Kibocsátó: Kutatási és Innovációs Főigazgatóság, (Európai Bizottság). Közzétéve: 2017.06.28. PDF ISBN 978-92-79-50580-5

Letöltés: 2020.04.04.

URL https://op.europa.eu/hu/publication-detail/-/publication/cd2940d1-fd4d-11e5-b713-01aa75ed71a1/language-en

${ }^{4}$ Az Európai horizont létrehozása - részvételi és terjesztési szabályainak megállapítása

Az Európai Parlament 2019. április 17-i jogalkotási állásfoglalása az Európai horizont kutatási és innovációs keretprogram létrehozásáról, valamint részvételi és terjesztési szabályainak megállapításáról szóló európai parlamenti és tanácsi rendeletre irányuló javaslatról (COM(2018)0435 - C8-0252/2018 - 2018/0224(COD)) (Rendes jogalkotási eljárás: első olvasat)

Letöltés: 2020.04.04.

URL https://www.europarl.europa.eu/RegData/seance pleniere/textes adoptes/provisoire/2019/04-17/0395/P8 TAPROV(2019)0395 HU.pdf

${ }^{5}$ Horizon Europe - Investing to shape our future. Based on the Commission Proposal for Horizon Europe, the common understanding between co-legislators and the Partial General Approach, both approved in April 2019. Version 25. Az Európai Bizottság prezentációja. 2019.05.

Letöltés: 2020.04.04.

URL https://ec.europa.eu/info/files/horizon-europe-investing-shape-our-future en

${ }^{6}$ Funding - Awareness - Scale - Talent (FAST) Europe is back: Accelerating breakthrough innovation.

European Commission Directorate-General for Research and Innovation Directorate B - Open Innovation and Open Science. Luxembourg: Publications Office of the European Union, 2018.

PDF ISBN 978-92-79-79349-3

Letöltés: 2020.04.04.

URL https://ec.europa.eu/info/sites/info/files/eic hlg bz web.pdf

${ }^{7}$ Haertwich, P.: Horizon Europe - Widening elements. HE Consultation Hungary 27/11 Version 25. Az Európai Bizottság prezentációja. 2019.05.

Letöltés: 2020.04.04.

URL https://nkfih.gov.hu/hivatalrol/hivatal-hirei/horizont-europa-konzultacios

${ }^{8}$ Proposal for a REGULATION OF THE EUROPEAN PARLIAMENT AND OF THE COUNCIL establishing the InvestEU Programme. Brussels, 6.6.2018 COM(2018) 439 final 2018/0229(COD)

és What is the InvestEU Programme. Az Európai Bizottság prezentációja.

Letöltés: 2020.04.04.

URL https://ec.europa.eu/commission/publications/investeu-programme en

${ }^{9}$ InvestEU: WHAT WILL IT FINANCE? Az Európai Bizottság prezentációja.

Letöltés: 2020.04.04.

URL https://ec.europa.eu/commission/sites/beta-political/files/budget-june2018-what-is-investeu_en.pdf

${ }^{10}$ Proposal for a REGULATION OF THE EUROPEAN PARLIAMENT AND OF THE COUNCIL establishing Horizon Europe - the Framework Programme for Research and Innovation, laying down its rules for participation 
and dissemination. Brussels, 7.6.2018 COM(2018) 435 final 2018/0224(COD)

Letöltés: 2020.04.04.

URL https://ec.europa.eu/commission/publications/research-and-innovation-including-horizon-europe-iter-andeuratom-legal-texts-and-factsheets en 